The Avoidance of Gold Bank Funds in

\title{
A evasão de ouro dos fundos bancários em meados do século XIX e suas consequências para a política econômica
}

middle of the nineteenth century and

their Consequences for Economic Policy

\section{Hernán Enrique Lara Sáez \\ Mestre e doutorando em História Econômica pela Universidade de São Paulo (FFLCH/USP - São Paulo/ Brasil) e bolsista da Fundação de Amparo à Pesquisa do Estado de São Paulo (FAPESP) e-mail: hernansaez@usp.br}

\begin{abstract}
Resumo
A transformação institucional de 1850 foi resultado de intensos debates no âmbito das instâncias legislativas brasileiras. Colateralmente, implicava um esvaziamento dos fundos bancários, especialmente, na praça carioca. A evasão de moeda ameaçou colocar em xeque o empenho de adequação do sistema bancário proposto pelo governo nesse periodo. Neste trabalho procuro identificar a posição dos responsáveis pelas políticas econômicas, como encaminharam essa situação e os reflexos destes na legislação do ano de 1860. Busco retomar não só o esforço em busca da estabilidade monetária como as frustrações pelos resultados obtidos e sua posterior reelaboração materializada na Lei dos Entraves. Utilizo como fonte os Relatórios dos Ministros da Fazenda e os Anais da Câmara dos Deputados. Esta artigo é resultado de uma pesquisa mais ampla que busca reconstituir a inter-relação entre as instâncias decisórias na questão monetária e bancária.
\end{abstract}

\begin{abstract}
Institutional change in 1850 was the result of intense discussions within the Brazilian legislative bodies and collaterally it implied an erosion of banking funds, especially in the Rio de Janeiro market. The avoidance of currency threatened the effort to adjust the banking system during this period. The article attempts to identify the stance of those who were in charge of economic policies, how they behaved and its consequences to the 1860 legislation. The article tries to access the pursuit of monetary stability and the frustrations with its results, but also the subsequent reworking embodied in the Lei dos Entraves. Its sources are the Ministers of Finance's reports and the Proceedings of the Imperial Parliament. The article results from a broader research project that seeks to reconstruct the interplay between the policies spheres that dealt with monetary and banking issues.
\end{abstract}

Palavras-chave

práticas políticas, legislação, comércio, tráfico interno de escravos

Keywords

political practices, legislation, trade, internal slave trade 
Introdução

Os planos econômicos discutidos na década de 1840 tiveram em vista recuperar a credibilidade da moeda e obter o crescimento da economia. Foram igualmente analisadas as espécies de moeda que seriam utilizadas e a proporção entre elas. Certamente, um dos grandes empecilhos à obtenção da estabilidade monetária estava na falta de moeda metálica, uma espécie de tendão de Aquiles no sistema do padrão-ouro brasileiro, pelo menos é o que se depreende de vários discursos da época. É preciso lembrar que, todos os projetos de melhoria da moeda pressupunham um mínimo de metais para dar solidez ao sistema bancário e monetário. Seus artífices envolveram-se

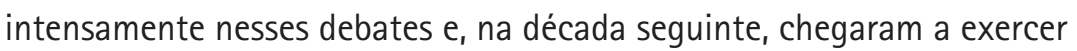
o cargo de Ministro da Fazenda. Desta forma, o empenho deles em obter um sistema bancário mais dinâmico estava vinculado a conseguir uma moeda mais estável. Os grandes temas deste momento foram: a natureza da moeda que circularia, o alcance das notas, a forma de substituir o meio em circulação e a configuração do sistema bancário.

Assim, a década de 1850 foi marcada pela implantação do projeto de melhoria do meio circulante. A aprovação da provincialização da moeda, em 1850, e a formação do banco nacional, em 1853, por exemplo, estiveram inseridas nesse esforço. No entanto, tais medidas não bastaram para configurar a economia da maneira como os legisladores ansiavam. As oscilações nas economias regionais e os reflexos de uma crise internacional colocavam em evidência muitas dificuldades entendidas como resultado de deficiências da moeda ou equívoco das políticas econômicas. 0 próprio ministro da Fazenda, Joaquim José Rodrigues Torres, destacou que os distúrbios apresentados pela praça comercial do Rio de Janeiro, em 1853, estavam ligados às deficiências do meio circulante, o que forçou os bancos a pedirem auxilio ao governo. As temáticas das discussões nesta época foram: os limites do crédito para a economia, a reconfiguração do sistema bancário, a luta visando a metalização dos fundos bancários e a defesa da reorganização do mercado financeiro.

Estes debates são fundamentais para se entender a legislação aprovada em 22 de agosto de 1860 . Visando o saneamento da economia brasileira, Ângelo Moniz da Silva Ferraz, ministro da Fazenda em 1860, obteve a aprovação pelo Legislativo de um projeto que previa, entre outras medidas, a metalização dos fundos bancários, a obrigatoriedade de realização das notas de banco por ouro à vontade do portador e a necessidade de autorização do governo para o funcionamento das sociedades anônimas. 0 impacto dessa legislação estava relacionado com uma grande contração do crédito e ao medo da falta de financiamento, especialmente, nas províncias mais distantes do Rio de Janeiro. A queda da emissão de notas bancárias certamente mudou o ambiente financeiro e, se por um lado enquadrou a economia buscando atrair ouro, por outro, limitou sua capacidade de financiamento institucional para as regiões mais afastadas. 0 texto, a seguir, busca elucidar o desenrolar desses debates e demonstrar o peso que tinha a preocupação da falta de ouro para todo o período entre 1850 e 1860.

\section{Um breve quadro econômico}

0 quadro econômico geral até meados do século XIX apresentava-se, resumidamente, na expressão da economia mercantil escravista. Os elementos principais eram: o trabalho escravo, a produção de gêneros 
1

MARTINS, José de Souza. 0 cativeiro da Terra. $8^{\text {a }}$ ed. São Paulo: Ed. Hucitec, 2004. p.26. Deputados, sessão de 13/06/1853, p.173. agrícolas e seu comércio com vistas ao mercado externo. Mais do que simplesmente mão-de-obra do latifúndio, o escravo era o ponto fundamental da economia. Segundo José de Souza Martins, "o escravo tinha a dupla função na economia da fazenda. De um lado sendo fonte de trabalho, era o fator privilegiado da produção. Por esse motivo era também, de outro lado, a condição para que o fazendeiro obtivesse dos capitalistas (emprestadores de dinheiro), dos comissários (intermediários na comercialização do café) ou dos bancos o capital necessário seja do custeio seja da expansão de suas fazendas. 0 escravo era o penhor de pagamento dos empréstimos. Por isso, praticamente todo capital de custeio provinha de hipotecas lançadas sobre a escravaria das fazendas". 'É a partir deste quadro geral que se devem matizar as transformações operadas com a aprovação da legislação em 1850, a tendência de aumento no valor dos cativos e as mudanças no sistema monetário e creditício brasileiro.

A lei sobre o fim do tráfico transoceânico de escravos repercutiu fortemente na economia mercantil escravista. Trouxe dificuldades à substituição da mão-de-obra gerando um problema na usual incorporação de novas terras, com vistas a garantir a manutenção ou aumento da produção. Curiosamente, neste mesmo período, a economia cafeeira passava por uma fase de expansão, o que representava, na praxis escravista, a pressão pelo aumento dos plantéis de escravos. Como explicar a adoção de uma legislação que rumava no sentido inverso das necessidades econômicas? Para entender esta aparente contradição é preciso lembrar que sua aprovação estava ligada à conjuntura internacional. A pressão inglesa pelo fim do tráfico tornara-se inapelável com a aprovação do Bill Aberdeen em 1845. Mesmo antes disso o Brasil já assinara acordos diplomáticos tendentes ao fim do tráfico sem, no entanto, coibir de maneira eficaz essa prática. Esta última determinação colocava o Brasil numa posição difícil frente ao poderio bélico da armada inglesa. 0 governo defrontava-se com a busca de uma solução salomônica.

Pressionado internamente pelos escravocratas e pelo avanço de exigências abolicionistas, o governo brasileiro também era pressionado externamente por uma potência que, cansada de atrasos na adoção de medidas efetivas por parte do governo brasileiro, decidiu pelo simples aprisionamento dos navios negreiros. A saída emergencial articulada pelo governo para enfrentar o dilema foi passar a identificar no translado dos escravos uma atividade perniciosa. Transfigurava-se, desta maneira, a antiga prática cotidiana em um elemento negativo que colocava em risco a soberania nacional. 0 governo, então, passou a identificar uma importante oposição entre os interesses ligados ao tráfico negreiro e à agricultura. Enquanto a primeira surgia como uma atividade aviltante, caracterizada pela simples especulação e avareza, a última aparecia como uma atividade civilizadora e geradora de riquezas. Nas palavras do deputado representante da província do Maranhão, João Duarte Lisboa Serra, um conservador moderado:

0 fato da cessação do tráfico africano fez respirar mais livremente os nossos lavradores, que até então julgavam que o único emprego legítimo do produto de seu trabalho era a compra de novos braços para aumentarem suas lavouras. Faltou esse emprego; as grandes dívidas que se haviam contraido puderam ir sendo amortizadas pela excelência das colheitas, e já não eram eles obrigados a deixar todo o produto de seu trabalho em certas e determinadas mãos na praça do Rio de Janeiro. ${ }^{2}$ 
MATTOS, IImar. 0 tempo Saquarema. $5^{\text {a ed. }}$ São Paulo: Ed. Hucitec, 2004. Especialmente "A restauração limitada", p.231-262.

4

VERGOLINO, J. R. 0. ; VERSIANI, Flávio. Preços de Escravos em Pernambuco no Século XIX. In: Anais do XX Encontro da Associação de Pós-Graduação em Economia XX. Rio de Janeiro: 2002. p.180205.
Desta forma, logrou manter-se a estrutura fundamental da economia escravista pela preservação do seu elemento mais importante, o escravo. Ao mesmo tempo demonstrava-se à opinião pública internacional que o governo conseguia impor suas determinações no âmbito do território nacional. E esta atitude favorecia a identificação da Coroa como promotora de medidas civilizadoras, como ressaltou IImar Mattos. Destarte, a aprovação da lei proibindo o tráfico representava a defesa da soberania, a manutenção da escravidão e um esforço do governo em fazer valer compromissos assumidos anteriormente. ${ }^{3}$

0 problema da evasão de moeda

Quadro 1- Gestões à frente do Ministério da Fazenda entre 1850-1860

\begin{tabular}{|l|l|l|l|}
\hline $06 / 10 / 1848$ & $10 / 05 / 1852$ & Joaquim José Rodrigues Torres & Visconde de Itaborai \\
\hline $06 / 12 / 1850$ & $13 / 01 / 1851$ & (Interino) Paulino José Soares de Souza & Visconde do Uruguai \\
\hline $11 / 05 / 1852$ & $11 / 02 / 1853$ & Joaquim José Rodrigues Torres & Visconde de Itaboraí \\
\hline $12 / 02 / 1853$ & $06 / 09 / 1853$ & (Interino) Manoel Felizardo de Souza e Melo & \\
\hline $06 / 09 / 1853$ & $12 / 01 / 1855$ & Honório Hermeto Carneiro Leão & Marquês do Paraná \\
\hline $12 / 01 / 1855$ & $27 / 01 / 1855$ & Antônio Paulino Limpo de Abreu & Visconde de Abaeté \\
\hline $27 / 01 / 1855$ & $23 / 08 / 1856$ & Honório Hermeto Carneiro Leão & Marquês do Paraná \\
\hline $23 / 08 / 1856$ & $04 / 05 / 1857$ & João Maurício Wanderley & Barão de Cotegipe \\
\hline $04 / 05 / 1857$ & $12 / 12 / 1858$ & Bernardo de Souza Franco & Visconde de Souza Franco \\
\hline $12 / 12 / 1858$ & $10 / 08 / 1859$ & Francisco de Sales Torres Homem & Visconde de Inhomirim \\
\hline $10 / 08 / 1859$ & $02 / 03 / 1861$ & Ângelo Moniz da Silva Ferraz & Barão de Uruguaiana \\
\hline
\end{tabular}

Fonte: BRASIL. Ministério da fazenda. http://www.fazenda.gov.br/portugues/institucional/ministros.asp

Conforme visto, logo após a lei do fim do tráfico de escravos, houve uma tendência à alta no valor dos cativos, o que não pode deixar de ser considerado na questão monetária porque representava um aumento de crédito aos senhores de escravos. Pode-se afirmar que esta alta estava relacionada a uma conjuntura mais ampla dessa época. Assim, ainda que não tenha sido apenas o combate ao tráfico que atuou sobre os valores, para o âmbito deste trabalho importa o fato de que houve aumento no valor dos escravos. Isso pode ser notado, por exemplo, através do estudo de Vergolino e Versani sobre o preço dos escravos no século XIX, em Pernambuco. ${ }^{4} \mathrm{~A}$ utilização desses dados mostra-se pertinente na medida em que aponta que a valorização ocorreu também em áreas sinalizadas como fornecedoras de escravos para a região Sudeste. Além do mais, o estudo sustenta que essa alta era uma tendência geral, mesmo para regiões fora do Brasil. De toda forma, não é o objetivo do presente estudo aprofundar-se na questão da escravidão, nem do tráfico interprovincial, porque fugiria tanto dos limites deste artigo quanto da pesquisa que the deu origem. 
Gráfico 1- Valor médio de escravos em Pernambuco durante o século XIX (autor: Hernán Enrique Lara Sáez)

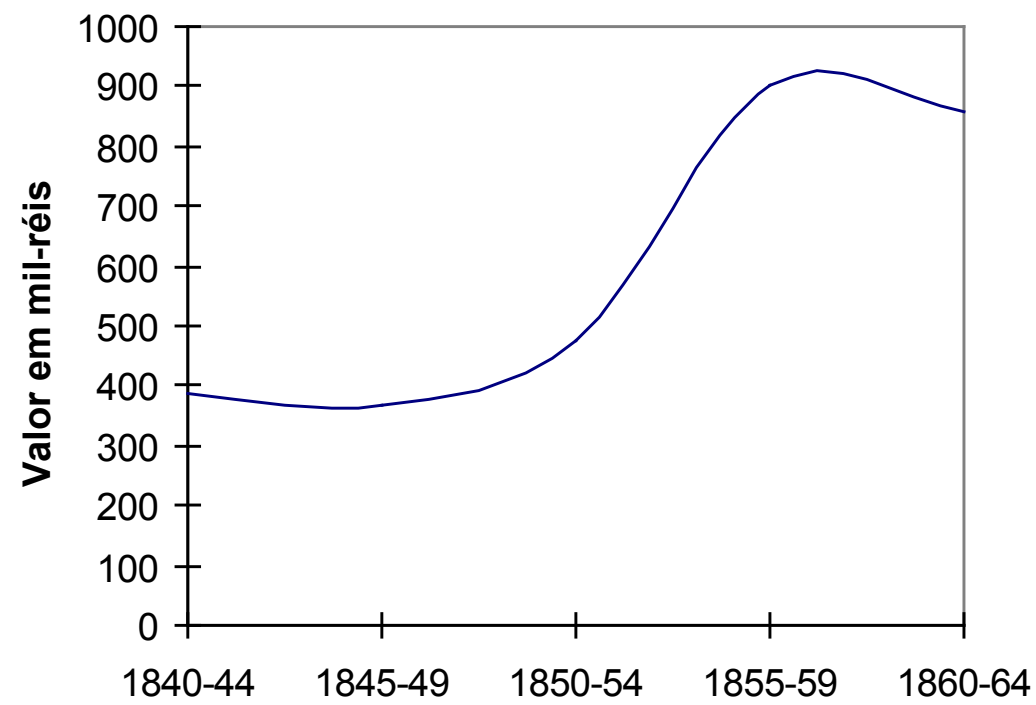

Fonte: VERGOLINO, J. R. O. ; VERSIANI, Flávio. Preços de Escravos em Pernambuco no Século XIX. Op. Cit. p.13.

Gráfico 2 - Plantel e preço do escravo em Pernambuco por quinquênios (1840-44 a 1865-69)

(autor: Hernán Enrique Lara Sáez)

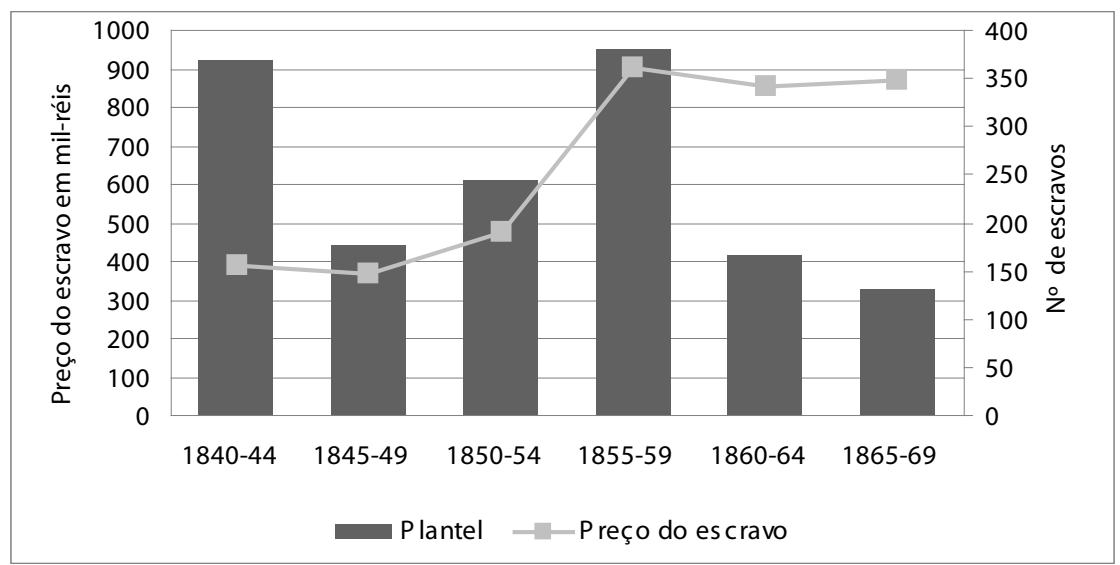

Fonte: VERGOLINO, J. R. O. ; VERSIANI, Flávio. Preços de Escravos em Pernambuco no Século XIX. Op. Cit.

MARTINS, José de Souza. 0 cativeiro da Terra..., Op. Cit., p.27, os valores que são apresentados em mil réis são os seguintes: para o período de 1848 1852 o preço do escravo era de $649 \$ 500$, para o periodo seguinte, entre 1853-1857, a soma passa para 1:177\$500, e para boa parte da década de 1860 (1863-1867), a soma foi de 1:817\$000.
Como se pode notar, a conclusão geral é que o preço do escravo tendeu a subir. Esta conclusão tem grande relevância caso se leve em conta que uma das alternativas para atender à expansão da produção cafeeira, ainda na vigência do regime de trabalho escravo, estava no tráfico interno. ${ }^{5}$ De mesma forma que se registrou a tendência de valorização do preço dos cativos não se pode ignorar a instabilidade da propriedade escrava, conforme se encontra no estudo de Beatriz Mamigonian. Ao tratar da escravidão neste período ela aponta uma contradição inerente à posse de escravos: enquanto a legislação apresentava brechas que podiam ser usadas para minar essa propriedade e diminuir-lhe o preço, os senhores de escravos coadjuvados pelo governo lutavam para mantê-la a salvo, no que foram relativamente bem sucedidos, pelo menos até meados de 1860 . Segundo esta autora: 
6

MAMIGONIAN, Beatriz G. O tráfico ilegal e a instabilidade da propriedade escrava no século $X I X$. p.4. Uma versão eletrônica deste trabalho pode ser encontrada no site: http://www.usp. $\mathrm{br} /$ feaecon/media/fck/File/BMamigonian_ Hermes\%20e\%20Clio.pdf
GIMARÃES, Carlos Gabriel. 0 Império e os bancos comerciais do Rio de Janeiro na segunda metade do século XIX: os casos do Banco Mauá, MacGregor \&t Cia., do Banco Rural e Hipotecário do Rio de Janeiro e do Banco Comercial e Agrícola. In: Anais do III Congresso Brasileiro de História Econômica e $4^{\text {a }}$ Conferência Internacional de História de Empresas. Uma versão eletrônica pode ser encontrada no seguinte endereço: http://www.abphe.org.br/ congresso 1999/Textos/CARL_4B.pdf

8

Anais da Câmara dos Deputados, sessão de 13/06/1853, p.159 e seguintes.
A ilegalidade da propriedade dos africanos importados depois de 1831 e de seus filhos e netos era reconhecida por todos, apesar de poucos a declararem publicamente. A propriedade sobre os africanos importados antes de 1831 e sua descendência crioula não era posta em questão, porém ninguém conseguia avaliar exatamente a proporção dos que seriam ilegais e nem garantir a ordem caso se aplicasse a lei. Assim, acreditava-se que a publicidade da ilegalidade de boa parte dos africanos geraria instabilidade na autoridade sobre todos os escravos. Em nome da 'razão de Estado', a ordem pública, os senhores de escravos e o governo insistiram incansavelmente na defesa do direito à propriedade. ${ }^{6}$

Retomando o tema das negociações entre o Rio de Janeiro e as diversas províncias do Império, a busca de escravos envolvia a transferência de somas cada vez maiores das praças do Sudeste para as outras regiões. Devido à organização peculiar do sistema monetário Imperial é necessário ponderar sobre quais tipos de recursos estavam sendo transferidos, vale dizer, que espécie de dinheiro estava sendo retirada, principalmente da economia fluminense, e injetada em outras localidades. Nesta época, existiam duas moedas de circulação geral no Império: as notas do tesouro e as moedas metálicas. Pelo valor intrínseco das últimas e credibilidade de ambas, elas eram procuradas para compor o fundo de reserva dos bancos de emissão. Assim, a transferência de grandes somas nestas espécies tendia a alterar a proporção legal entre a emissão e os fundos dos bancos descortinando a falta de solidez do sistema e ameaçando a suspensão do troco de notas bancárias em momentos de crise.

Aos contemporâneos, envolvidos nas discussões sobre a economia Imperial, não escapou o fato de que era preciso levar em conta o momento econômico da praça carioca, expansão ou retração, e como isso se refletia no comércio entre as economia regionais. Foi assim, por exemplo, com os problemas financeiros dessa região em 1853, que forçaram os bancos fluminenses a recorrer ao governo em busca de auxílio. Segundo Carlos Gabriel Guimarães, o atraso no funcionamento do Banco Rural e Hipotecário do Rio de Janeiro estava relacionado não só com a proibição pelo governo imperial do banco Rural ser um banco emissor, como "aos problemas comerciais que levaram a praça do Comércio do Rio de Janeiro a uma 'crise', com várias firmas comerciais fechando as suas portas por falta de dinheiro".7 Destaca-se na defesa do empréstimo, João Duarte Lisboa Serra, que expressou seu apoio ao projeto fundamentando-o com um extenso retrospecto das fases pela qual a economia carioca havia passado. Segundo ele, era possivel vislumbrar duas fases distintas "uma que chamarei das facilidades, e outra dos apertos (...)". A primeira época remontava ao ano de 1851 e estava relacionada com a liberação de avultados capitais. Estes chegavam ao montante de mil contos de réis, até então empregados no "comércio para a costa d'África". ${ }^{9}$ Nesta época, a alta do câmbio associada a uma taxa de juros favorável permitiu a entrada de metais criando uma espécie de desequilíbrio virtuoso na circulação monetária. Realmente, como se pode notar, os dados sobre o câmbio corroboram a versão do deputado.
9

lbidem. 
Tabela 1 - Taxa de câmbio média mensal da libra esterlina (réis por pence) nas diversas Praças

(autor: Hernán Enrique Lara Sáez)

\begin{tabular}{|c|c|c|c|}
\hline & RJ & BA & PE \\
\hline 1850 jan & 28,5 & 27,9 & 27,9 \\
\hline Mai & 27,875 & 27,5 & 27 \\
\hline 1851 jan & 30,125 & 30,1 & 30 \\
\hline Mai & 29,125 & 28,9 & 28,1 \\
\hline 1852 jan & 27,5 & 28,1 & 27,5 \\
\hline Maio & 26,750 & 27 & 27,8 \\
\hline 1853 jan & 28 & 28,9 & 28,6 \\
\hline Mai & 28,5 & 27,9 & 28,3 \\
\hline 1854 jan & 28,375 & 27,3 & 28 \\
\hline Mai & 27,188 & 27,5 & 27 \\
\hline 1855 jan & 27,875 & 28 & 28 \\
\hline Mai & 27,438 & - & 27,5 \\
\hline 1856 jan & 27,750 & 28,5 & 28,8 \\
\hline Mai & 27,500 & 28 & 27,3 \\
\hline 1857 jan & 27,813 & 27,4 & 28,4 \\
\hline Mai & 27,750 & 27,9 & 28 \\
\hline 1858 jan & 25,125 & 23,3 & 33,5 \\
\hline Mai & 25,500 & 25,3 & 25,3 \\
\hline 1859 jan & 25,750 & 26,8 & 26,1 \\
\hline Mai & 25 & 24,3 & 26,8 \\
\hline 1860 jan & 24,563 & 25,3 & 25,3 \\
\hline Mai & - & 25,3 & 25,5 \\
\hline
\end{tabular}

Fonte: IPEADATA. Obs.: Tomou-se maio como uma das datas de referência porque era o mês no qual foi apresentado a maioria dos Relatórios do Ministério da Fazenda.

Nessa conjuntura, o mecanismo do padrão-ouro teria garantido que essa situação atraisse cada vez mais capital sob forma de metais que prontamente eram amoedados e entravam em circulação. A ocasião era tão favorável que fazia com que o ouro extraído no Brasil permanecesse aqui, porque dificilmente encontraria uma situação tão auspiciosa a ponto de cobrir os custos de envio. Segundo o deputado, todo este quadro favoreceu a expansão do crédito que, por sua vez, animou os negócios e estabeleceu facilidades às empresas de toda natureza.

0 comércio interprovincial também se aqueceu, especialmente os negócios com as províncias "do Norte" - correspondente ao atual Nordeste. Muitas delas, como por exemplo, Pernambuco, Bahia e Maranhão, aumentaram o envio de excedentes para o mercado carioca e receberam em troca centenas de contos de réis em notas do tesouro e ouro, criando maiores incentivos ao aumento da produção. ${ }^{10} 0$ reflexo disso foi uma evasão gigantesca de meio circulante da região fluminense, que ainda deveria 
11

Idem, sessão de 30/05/1853. p.317 e 318.

12

CARVALHO, José Murilo de. 0 teatro das sombras. Rio de Janeiro. Civilização Brasileira, 2003. p.337.
Ministério da Fazenda. Proposta e relatório apresentados á Assembléia Geral Legislativa na Terceira Sessão da Nona Legislatura pelo Ministro e Secretário d'Estado dos Negócios da Fazenda Marquês do Paraná. Rio de Janeiro: Typ. Nacional, 1855. p.9. fazer frente ao aquecimento de sua economia pela expansão das atividades cafeicultoras e comerciais.

A época dos apertos foi assinalada pelo momento em que os dois principais bancos da província do Rio de Janeiro pediram ajuda ao governo. 0 motivo do pedido foi, segundo os discursos, a crise do "mercado monetário". As observações do então ministro da Fazenda, Joaquim José Rodrigues Torres, futuro Visconde de Itaboraí, um dos líderes do Partido Conservador e seu principal economista, confirmavam a existência dos embaraços comerciais que podiam ser creditados à deficiência do meio circulante. Ele sinalizava que apoiava a liberação do empréstimo aos bancos como forma de impedir uma retração econômica que, fatalmente, acabaria atingindo o governo através da queda da arrecadação. ${ }^{11}$

A mesma situação figuraria mais tarde nos Relatórios dos Ministros da Fazenda. Em 1854, por exemplo, o ministro da Fazenda, Honório Hermeto Carneiro Leão, Marquês do Paraná, um nome de peso entre os conservadores e cafeicultor no Rio de Janeiro, tratou de uma solicitação feita pelo Banco do Brasil para o aumento de sua emissão além do duplo do seu fundo disponivel. ${ }^{12} 0$ motivo que o banco alegava é muito significativo com relação ao problema da evasão de moeda das economias do Sudeste. Dizia o banco que havia afluência excessiva de seus bilhetes para substituição por notas de circulação geral no Império. Explicava que desde o começo do ano decorriam continuas remessas de papel-moeda e metais para as províncias do "Norte" e esta situação o forçou a romper a relação entre emissão e fundo de reserva, levando-o, posteriormente, à suspensão do desconto de seus bilhetes. Para contornar esta situação o banco realizou uma chamada de capital, mas antevia que a maior parte dos capitais que porventura entrasse em seus cofres seria de seus mesmos bilhetes e não de metais. Finalmente, chegava à conclusão que tanto ele, quanto outros estabelecimentos de crédito não tinham outra saída a não ser contrair seus descontos em um momento de expansão dessa economia, o que claramente traria transtornos ao comércio.

Em resposta ao pedido dos bancos o ministro afirmava que, a diferença entre emissão e fundo ainda era pequena e não fundamentava a alteração entre os dois. Frisava que mesmo no trato cotidiano era difícil manter a proporção durante todo o tempo. Segundo o Marquês do Paraná, a diferença neste caso poderia ter sido ajustada pela simples elevação da taxa de desconto.

Com efeito a saída nos meses anteriores de avultadas quantias em metal e papelmoeda para a compra de safras e escravos do Norte, e para outros diversos destinos, produziram no mercado um vazio que dificultava ao Banco a conservação do seu fundo disponivel na medida indispensável ao desenvolvimento de suas operações e este fato ocorrido na proximidade da época, em que na praça do Rio de Janeiro se tinham que efetuar numerosas liquidações, começava a reagir sobre a confiança e a sortir os efeitos que costumavam ser prelúdio das crises comerciais. ${ }^{13}$ (Grifo meu)

Apesar do ministro argumentar diversas vezes contrariamente ao pedido, no final, o aumento de emissão foi concedido pelo espaço de um ano com inúmeras ressalvas. Entre elas, o governo assegurava a opção de revogá-lo antes do fim desse prazo, a medida tinha caráter temporário e condicional e estava vinculada a cláusulas que impossibilitariam o uso deste recurso no futuro e, por último, estava ligada às condições da circulação e às necessidades reais do comércio. A desconfiança na concessão da medida 
CARVALHO, José Murilo de. 0 teatro das sombras..., Op. Cit., p.302.

15

Ministério da Fazenda. Proposta e relatório apresentados á Assembléia Geral Legislativa na Primeira Sessão da Décima Legis/atura pelo Ministro e Secretário d'Estado dos Negócios da Fazenda João Maurício Wanderley. Rio de Janeiro: Typ. Nacional, 1857. p.17.

16

Idem. Proposta e relatório apresentados á Assembléia Geral Legislativa na Terceira Sessão da Oitava Legislatura pelo Ministro e Secretário d'Estado dos Negócios da Fazenda Joaquim José Rodrigues Torres. Rio de Janeiro: Typ. Nacional, 1851. p.35.

17

Idem. Proposta e relatório apresentados á Assembléia Geral Legislativa na Quarta Sessão da Décima Legislatura pelo Ministro e Secretário d'Estado dos Negócios da Fazenda Ângelo Moniz da Silva Ferraz. Rio de Janeiro: Typ. Nacional, 1860. p.69 estava na tendência ao excesso de emissão dos bancos em busca do lucro.

Em 1855, o ministério esteve sob a orientação do baiano João

Maurício Wanderley, Barão de Cotegipe, conservador e senhor de engenho, que fora, em 1850, chefe da polícia na Bahia e se destacara no combate ao tráfico. Ele também fez menção ao mesmo fenômeno, o que indica que a situação da evasão metálica não se tratava somente de um evento passageiro. ${ }^{14}$

É fato constante dos últimos balanços do Banco do Brasil que de junho de 1855 até fim de março último, tem este estabelecimento importado cerca de vinte mil contos de ouro, e que, não obstante isso, e a operação do troco de notas de $50 \$$ de que vos deu conta o relatório anterior, o fundo disponivel apenas teve de então para cá o aumento de 4.000 contos; donde se vê que tem havido e continua a haver uma permanente exportação de moeda deste para outros mercados do Império, e talvez para algumas praças estrangeiras. ${ }^{15}$

A saída de metais da praça carioca mostrou-se persistente por quase toda a década. A impressão que muitas vezes se tem ao acompanhar a busca de soluções para os problemas monetários é que as demais províncias atuariam como sorvedouros de moeda, o que de certa forma era uma realidade. É preciso ter em mente que além de existirem outras praças com economias em crescimento, como era o caso de algumas praças do Norte, havia também o fenômeno da abertura de novos núcleos populacionais com áreas produtivas que igualmente demandavam moeda. Não fosse apenas estes fenômenos, o governo, na contramão da expansão, trabalhava no sentido de retirar de circulação os bilhetes de baixo valor e substituí-los por notas de valores mais elevados. Foi assim em 1851 quando o então ministro da Fazenda, Joaquim José Rodrigues Torres, afirmou que substituiria os bilhetes de $1 \$$ e $2 \$$ por moedas de prata ou os converteria em notas de maior valor, conforme as circunstâncias se apresentassem. ${ }^{16}$

0 esforço realizado pelo Visconde de Itaboraí no começo da década também foi exposto ao final dela por Ângelo Moniz da Silva Ferraz, futuro Barão de Uruguaiana, que tratava de elucidar os motivos dessa atitude.

Os bilhetes, ou notas dos Bancos são em regra destinados para facilitar as transações dos negociantes de grosso trato entre si, ou as que se operam entre estes e os de retalho. Esta é a sua missão, este círculo em que devem exercer suas funções; mas no cálculo dos lucros os bancos prescindem do uso desses bilhetes ou notas de pequeno valor, que quase exclusivamente são aplicados entre os comerciantes de retalho e os consumidores, e que mui proveitoso lhes é, embora com sacrifícios de interesses de maior monta. ${ }^{17}$ (grifo meu)

Deste modo, a aparente falta de percepção sobre a economia real estava ligada à crença que alguns políticos deste momento sustentavam. Havia duas razões que legitimavam, aos olhos daqueles que voltaram suas preocupações para os problemas monetários, esse modo de agir. Esta atitude estava de acordo com uma corrente de pensamento que enxergava no dinheiro de papel uma função específica: ele deveria ser empregado nas grandes negociações ficando longe das pequenas transações do dia-adia. Além disso, não se pode esquecer a crença fundamental daqueles que confiavam nas regras do padrão-ouro, vale dizer, uma vez inserido em um circuito comercial mais amplo e adotando os preceitos gerais do sistema ouro, como era o caso do Brasil naquela época, a localidade em que houvesse disponibilidade de produtos e falta de dinheiro acabaria por apresen- 
SANDRONI. Paulo. Dicionário de economia do século XXI. Rio de Janeiro. Record, 2005. p.475.

Sobre as posições político-partidárias consultar CARVALHO, José Murilo de. A construção da Ordem, ou, 0 teatro das sombras. Rio de Janeiro. Civilização Brasileira, 2003 ou recorrer ao trabalho de ABREU, Eide Sandra de Azevedo de. 0 evangelho do comércio universal. 0 desempenho de Tavares Bastos na Liga Progressista e no Partido Liberal (1861-1872). Tese de doutoramento, Universidade Estadual de Campinas, Campinas, 2004. tar uma relação favorável ao possuidor de moeda (metálica) e ele obteria maior quantidade do produto por menor quantidade de moeda. Essa situação se sustentaria até que entrasse em ação o mecanismo de correção do sistema, quando a localidade já estivesse devidamente abastecida de moeda e os produtores mudassem a relação entre mercadorias e moeda.

Descortinava-se neste ponto um ranço perene na crença a esse sistema, a saber, mesmo que as novas áreas fossem sorvedouros de moeda metálica da praça carioca, ela jamais poderia ficar sem moeda uma vez que, alinhado como estava o Brasil às regras do padrão-ouro, essa espécie deveria naturalmente afluir para o Rio de Janeiro. A resposta formulada para esse incômodo problema baseava-se na Lei de Gresham, ela enunciava que quando duas moedas têm circulação legal em um dado país, a moeda má expulsa a boa de circulação. ${ }^{18}$ No caso brasileiro, afirmava-se que a emissão em excesso do papel-moeda espantava o ouro das praças comerciais. 0 motivo era que a "moeda-papel" assumiria o lugar da moeda metálica e, neste caso, a relação favorável produtos/moeda não se daria. Soma-se a isto o fato de ser um fundamento amplamente difundido que 0 aumento do papel-moeda levava ao aumento de preços. Tais idéias davam argumentos à obsessão ao combate à emissão que perpassou parte do período Imperial.

Voltando a atenção para a série de Relatórios dos Ministros da Fazenda é possivel perceber algumas variações interessantes na forma como as diferentes gestões abordaram os problemas econômicos. Algumas tenderam a dar maior relevância ao aspecto teórico. Nestes não é difícil encontrar um apelo à ciência (econômica) e aos financistas. É o caso, por exemplo, das administrações de Joaquim José Rodrigues Torres, Bernardo de Souza Franco, o Visconde de Souza Franco, de tendências liberais que nesta época já estabelecera a fama de grande conhecedor na área econômica e Francisco de Sales Torres Homem, o Visconde de Inhomirim, conservador de posições mais ortodoxas em matéria de políticas econômicas e, por último, Ângelo Moniz da Silva Ferraz. Notou-se que estas preocupações foram expostas em gestões que pretenderam explicar, nos Relatórios, os motivos pelos quais adotaram ou modificaram algumas medidas econômicas, buscando com isso fundamentar suas atitudes no saber teórico.

Outras gestões apresentaram relatórios mais sintéticos, com menos recorrências aos modelos teóricos e mais voltados para informar a situação e os reflexos da adoção de algumas medidas já implementadas. Foi o caso das gestões de Honório Hermeto Carneiro Leão e João Maurício Wanderley. Este, por exemplo, concedeu apenas uma página ao item Bancos em seu relatório. Pode-se supor que os Relatórios não são o melhor campo para colher este tipo de informação, uma vez que não existia o questionamento sobre a legitimidade ou os fundamentos da adoção de uma política especifica. Suponho que, para ter uma visão mais nítida destes fundamentos, é mais efetivo recorrer aos pronunciamentos dos respectivos ministros nas sessões legislativas onde eram chamados para darem esclarecimentos das medidas ou planos que pretendiam adotar. No entanto, é importante ressaltar que a menção às teorias econômicas nunca saiu completamente de cena. ${ }^{19}$

Aparentemente, o que se apresentou foi um discreto abandono dos modelos teóricos a favor da prática que poderia trazer melhores resultados para problemas e situações mais específicas para o caso brasileiro. Desta forma, é preciso lançar vistas ao triênio 1857-1860, um momento marcado 
GUIMARÃES, Carlos Gabriel. 0 Império e os bancos comerciais do Rio de Janeiro na Segunda metade do século XIX... Op. Cit. por uma série de tensões, pela luta em prol da adoção de novos projetos de política econômica e por uma crescente divergência na apreciação das questões que encaminhava para uma nova ordenação dos partidos políticos. Portanto, para apreender melhor estas tensões é preciso retornar à subida de Bernardo de Souza Franco, ao ministério da Fazenda.

Sua atuação foi marcada pelo reflexo de uma crise econômica mundial. Segundo Carlos Gabriel Guimarães, "No momento em que os bancos emissores regionais tiveram autorização para começar suas operações, a retomada das exportações russas de cereais fez com que eclodisse em nova York uma espetacular queda nos preços das commoditys, repercutindo em cadeia pela Europa Ocidental, atingindo bancos e bolsas. Esse abalo dos preços interrompeu uma alta geral dos preços provocada, por entre outros fatores, pela descoberta de ouro da Califórnia e da Austrália no início da década de 1850"..$^{20}$ Assim, antes de prosseguir no desenrolar dos planos econômicos do triênio será útil verificar alguns índices do período.

As instabilidades de 1853 e 1857: alguns índices do período

Gráfico 3 - Inflação - Custo de vida - alimentação - ponderação escravos 1856 - cidade do Rio de Janeiro - índice (média $1820=100$ )

(autor: Hernán Enrique Lara Sáez)

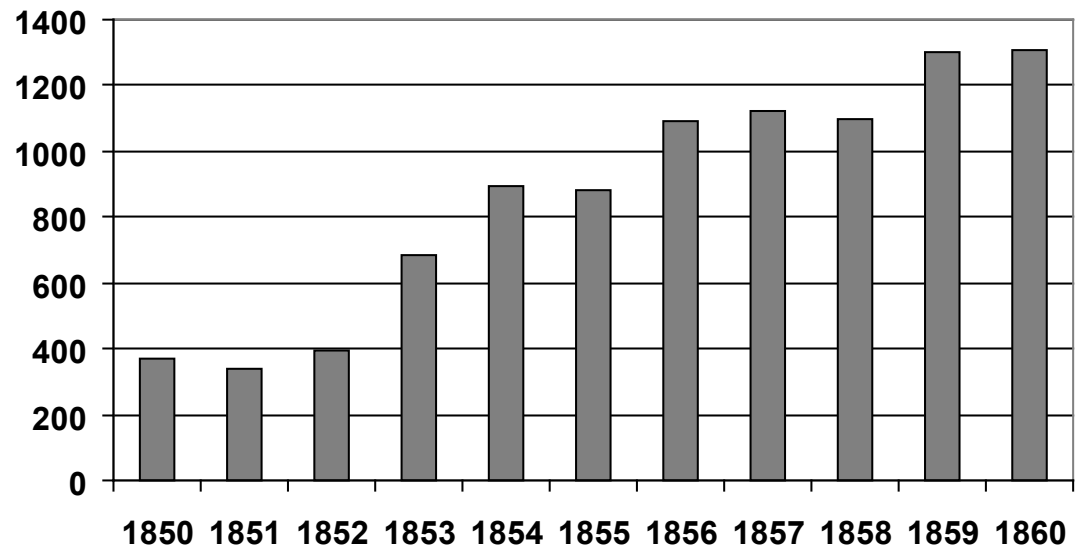

Fonte: IPEADATA.

0 gráfico acima indica uma baixa do custo de vida no começo da década de 1850. Sabe-se que a economia se aqueceu, nesse momento, pela disponibilidade de recursos que deixaram de ser empregados no tráfico e passaram a ser disponibilizados para outras atividades. Aparentemente, houve uma tendência generalizada da elevação do custo de vida no Rio de Janeiro durante toda a década, com aceleração desse aumento entre os anos de 1853/1854, 1856/1857 e 1859/1860. Assim, de fato, o custo de vida mostrava-se elevado nos dois momentos percebidos pela praça carioca como de instabilidade, 1853 e 1857. Por sua vez, mesmo no final da década, com a guinada na política econômica posterior à gestão Bernardo de Souza Franco, o custo de vida não sofreu retração mas, pelo contrário, aumentou. Curiosamente, o que se pode notar é que, na gestão do Visconde de Souza Franco, não só o custo de vida se manteve no nível do ano anterior, como retrocedeu ligeiramente em 1858. E teve um súbito aumento nas duas gestões posteriores. 
21

MAGALHÃES Jr., Raymundo. Três panfletários do segundo reinado. São Paulo. Ed. Nacional, 1956.
Talvez estes dados ajudem a entender a veemência dos ataques das gestões de Francisco de Sales Torres Homem e Ângelo Moniz da Silva Ferraz, à frente do ministério da Fazenda contra o Visconde de Souza Franco. Isso porque a opinião pública exercia um papel nada desprezível na definição das medidas adotadas no Parlamento. É preciso ter em mente que as sessões do Legislativo tinham publicidade através dos jornais como, por exemplo, o Jornal do Comércio, mas também porque vários políticos escreviam nos jornais sob pseudônimos, tratando de mobilizar apoio às idéias que defendiam. Foi o caso do ministro Torres Homem que, sob a alcunha de Timandro, se esforçava em difundir suas posições e fundamentá-las. ${ }^{21}$ Portanto, os ministros da Fazenda estavam sob pressão das circunstâncias e sob a atenção da opinião pública, para que estes índices passassem a ser mais favoráveis. Claro está que este índice isolado não consegue dar conta da situação da época, daí a intenção de ampliar a análise dos dados do período.

Gráfico 4- Exportações entre 1850 e 1860

(autor: Hernán Enrique Lara Sáez)

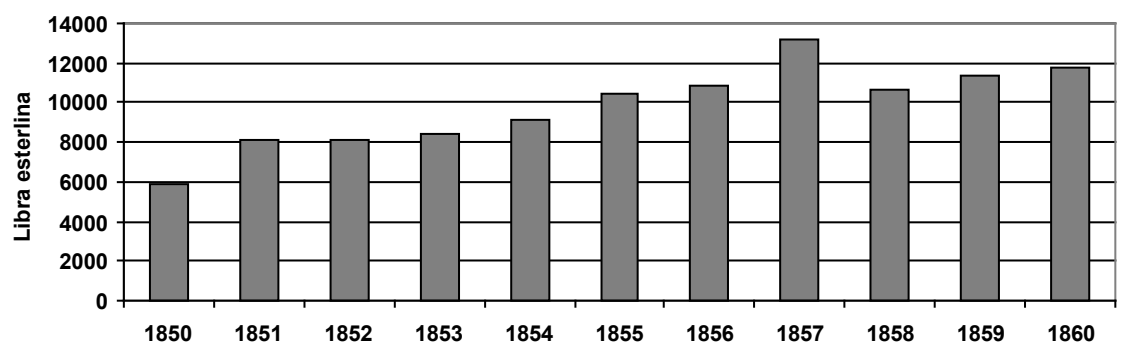

Fonte: IPEADATA.

Gráfico 5 - Importações entre os anos de 1850 e 1860

(autor: Hernán Enrique Lara Sáez)

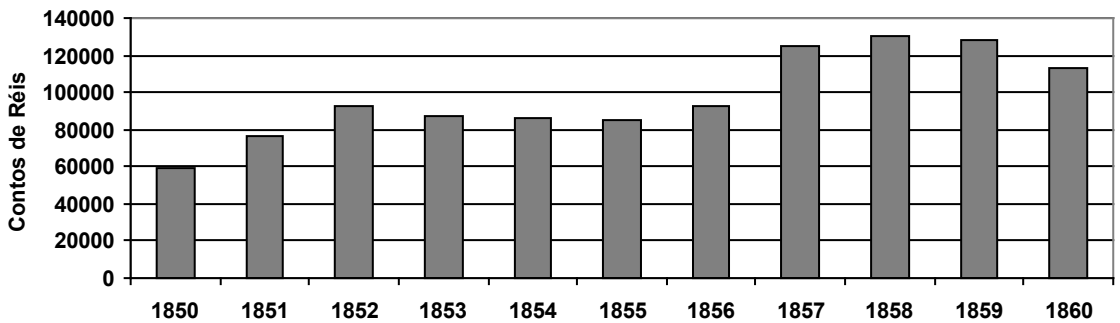

Fonte: IPEADATA.

Com relação à exportação, houve uma ligeira retração entre os anos de 1851 e 1852, seguindo-se uma escalada até 1857. Deste momento em diante, até 1860, o índice cai e não volta ao nível de 1857. Deslocando a atenção para os dados referentes à importação a situação é a seguinte. Até 1852 , houve um contínuo aumento da importação, com uma queda entre os anos de 1853 até 1855 . Seguiu-se uma retomada de crescimento até 1858 , quando novamente se verifica uma tendência à queda. Chama a atenção 0 índice referente ao ano de 1860, pois apresenta o pior resultado desde 1857.

De modo geral, estes índices corroboram as indicações dos discursos políticos de que houve uma instabilidade em 1853, mas tanto os discursos 
quanto o projeto de auxílio aos bancos afirmavam que ela estava restrita à praça do Rio de Janeiro e teve caráter comercial, influindo apenas de maneira indireta na economia das demais regiões. Não se pode ignorar que o governo manifestou preocupação com a situação e chegou a elaborar um plano para auxílio dos bancos. Essa atitude, provavelmente, serviu para acalmar a praça e impedir um aprofundamento da crise. Diferente do que se encontra no final da década. De fato, como já apontado pelo trabalho de Carlos Gabriel Guimarães, a instabilidade desse momento foi dada por uma crise econômica mundial. Apesar do crescimento das exportações em 1857, os anos de 1858 e 1859 foram menos auspiciosos, com uma queda tanto nas exportações como nas importações, e uma tendência a alta no custo de vida no Rio de Janeiro entre os anos de 1859 e 1860.

Gráfico 6 - Exportações - café em grão - 1850 a 1860

(autor: Hernán Enrique Lara Sáez)

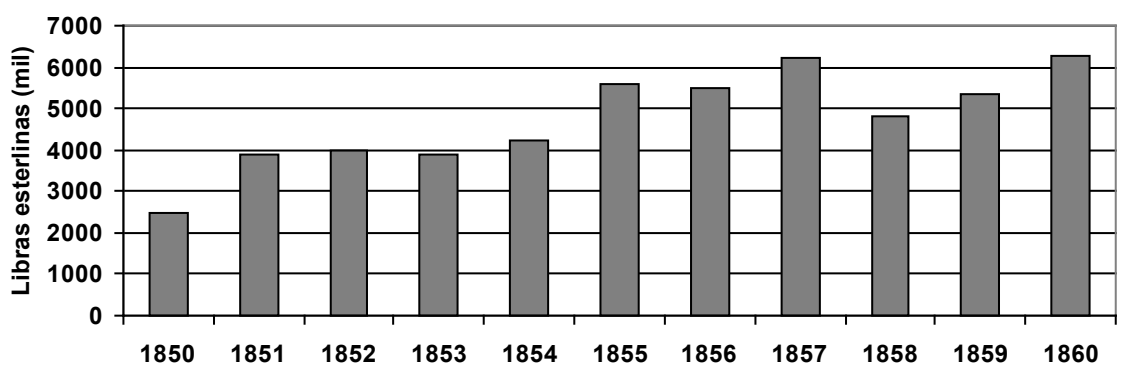

Fonte: IPEADATA.

Mesma tendência se encontra caso se isole o café na pauta de exportação brasileira. Há uma alta entre 1850 e 1852, com breve recuo em 1853, e novo crescimento entre 1854 e 1857, com desaceleração em 1856. No entanto, depois de 1857, há uma sensivel diminuição do índice, com uma recuperação apenas no ano de 1860. Esta é uma informação importante caso se leve em conta que, as áreas do Sudeste, em especial o Rio de Janeiro e São Paulo, se destacaram a partir deste período na produção cafeeira. Assim, o que se pode notar pelo gráfico, são reflexos na exportação deste produto em 1853, e de maior intensidade em 1858.

Gráfico 7 -Preço médio - café - quilo

(autor: Hernán Enrique Lara Sáez)

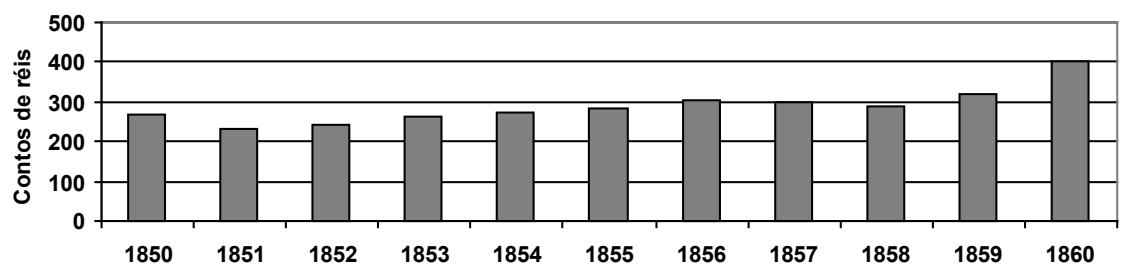

Fonte: IPEADATA.

Também é importante acompanhar o preço do café no período. A despeito de não ter havido grandes flutuações - salvo no ano de 1860 - 0 que se pode notar é uma retração dos preços entre os anos de 1851 e 1852 e em 1858, com uma rápida recuperação a partir de 1859. A curva da média 
do preço do café tem um desenho muito parecido com a do aumento de exportações do produto, apontando uma tendência de valorização na década de 1860.

De tudo o que foi exposto, e atendo-se aos limites e objetivos deste artigo, nota-se um período conturbado com relação aos índices econômicos da segunda metade da década de 1850 . A agitação causada pelo impacto da crise mundial pós-1857 certamente serviu para acirrar os ânimos nos debates políticos. Pelo menos é o tom que se encontra neste momento nos discursos, bem diferente do tom dos debates em 1856. 0 periodo que vai de 1857 a 1860 foi marcado pelo confronto entre expansão do crédito através dos bancos provinciais e pela adoção de medidas que previam sua contração. Os dados foram utilizados nos debates, mas ganhavam outro significado quando inseridos nas argumentações dos políticos. Isso pode ser devidamente apreciado, por exemplo, nas críticas aos resultados da política do Visconde de Souza Franco. Elas se preocupavam menos em elucidar até que ponto os problemas enfrentados pela economia brasileira estavam relacionados com a crise econômica internacional ou se eram resultado da adoção da política de pluralidade bancária.

\section{Os planos econômicos do triênio 1857 a 1860}

Quadro 2 - Quadro com os Gabinetes do período de 1857 a 1860 por pastas (autor: Hernán Enrique Lara Sáez)

\begin{tabular}{|l|l|l|}
\hline $\begin{array}{l}\text { Ano em que } \\
\text { assume }\end{array}$ & 1857 & Gabinete: 13 (4 de maio) \\
\hline Presidente & Marquês de Olinda & Pedro de Araújo Lima \\
\hline Império & Marquês de Olinda & Pedro de Araújo Lima \\
\hline Justiça & Francisco Diogo Pereira de Vasconcelos & \\
\hline Estrangeiros & Visconde de Maranguape & Caetano Diana Lopes da Gama \\
\hline Fazenda & Visconde de Souza Franco & Bernardo de Souza Franco \\
\hline Marinha & José Antônio Saraiva & \\
\hline Guerra & Jerônimo Francisco Coelho & \\
\hline
\end{tabular}

\begin{tabular}{|l|l|l|}
\hline $\begin{array}{l}\text { Ano em que } \\
\text { assume }\end{array}$ & 1858 & Gabinete: $14^{\circ}$ (12 de Dezembro) \\
\hline Presidente & Visconde de Abaeté & Antônio Paulino Limpo de Abreu \\
\hline Império & Sérgio Teixeira de Macedo & \\
\hline Justiça & José Tomas de Nabuco de Araújo & \\
\hline Estrangeiros & Visconde do Rio Branco & José Maria da Silva Paranhos \\
\hline Fazenda & Visconde de Inhomirim & Francisco de Sales Torres Homem \\
\hline Marinha & Visconde de Abaeté & Antônio Paulino Limpo de Abreu \\
\hline Guerra & Visconde do Rio Branco & José Maria da Silva Paranhos \\
\hline
\end{tabular}

\begin{tabular}{|l|l|l|}
\hline $\begin{array}{l}\text { Ano em que } \\
\text { assume }\end{array}$ & 1859 & Gabinete: $15^{\circ}$ (10 de Agosto) \\
\hline Presidente & Barão de Uruguaiana & Ângelo Moniz da Silva Ferraz \\
\hline Império & Barão de Uruguaiana & Ângelo Moniz da Silva Ferraz \\
\hline Justiça & Marquês do Paranaguá & João Lustosa da Cunha Paranaguá \\
\hline Estrangeiros & Visconde de Sinimbu & João Lins Vieira Cansanção Sinimbu \\
\hline Fazenda & Barão de Uruguaiana & Ângelo Moniz da Silva Ferraz \\
\hline Marinha & Francisco Xavier Pais Barreto & \\
\hline Guerra & Sebastião do Rego Barros & \\
\hline
\end{tabular}

Fonte: JAVARI, Jorge João Dodsworth. Organizações e Programas ministeriais: Regime Parlamentar no Império. Rio de Janeiro: Arquivo Nacional, 1962. 
22

Extraído de NABUCO, Joaquim. Um estadista do império: Nabuco de Araújo, sua vida, suas opiniões, sua época. Vol 1. Rio de Janeiro: Civilização Brasileira S/A., 1936. p.129.
23

Anais da Câmara dos Deputados, sessão de 5 de agosto de 1857. p.89 (Apêndice).
SÁEZ, Hernán Enrique Lara. Nas asas de Dédalo: um estudo sobre o meio circulante no Brasil entre os anos de 1840 a 1853. Mestrado em História. Faculdade de Filosofia, Letras e Ciências Humanas, da Universidade de São Paulo, 2008. Especialmente a parte: 0 s debates sobre o meio circulante, p.74.
A ascensão de Bernardo de Souza Franco ao ministério da Fazenda estava inserida nos marcos da política da conciliação. Nada melhor do que um dos envolvidos neste triênio para definir do que se tratava essa prática.

Entre a decadência dos partidos velhos que acabaram seu tempo e o aparecimento dos partidos novos a quem o porvir pertence, virá assim interpor-se uma época sem fisionomia, sem emoções, sem crenças entusiásticas, mas que terá a inapreciável vantagem de romper a continuidade da cadeia de tradições funestas e de favorecer pela sua calma e por seu silêncio o trabalho interior de reorganização administrativa e industrial do país (...). ${ }^{22}$

Esta descrição foi realizada por Francisco de Sales Torres Homem, em 1857, cerca de um mês após o Visconde de Souza Franco assumir a gestão do ministério da Fazenda. Este momento foi marcado pela Conciliação, um arranjo político que, longe de significar a ausência de partidos ou sua supressão, tratava-se de uma aproximação das alas moderadas dos dois maiores partidos imperiais, o conservador e o liberal, gerando uma espécie de consenso sobre a agenda política do período. Desta forma, logrou-se debater questões entendidas pela maioria como fundamentais para 0 Brasil, sem que as determinações partidárias se sobrepusessem aos temas. Esse predomínio das alas moderadas propiciou a ascensão de um "antigo" liberal com planos bem articulados que se mostrara, desde a década de 1840, francamente partidário à instalação de bancos provinciais com suas atividades voltadas para uma ou mais províncias e emissões baseadas no movimento comercial e dando maior ênfase à ampliação do crédito como solução para alguns problemas.

No entanto, a questão econômica, ou como muitas vezes era chamada, a questão financeira, estava longe de correr com a calma e serenidade com que os deputados gostavam de referir-se à conciliação. Pelo contrário, o fim da década de 1850 foi fortemente marcado por acalorados debates, por trocas de acusações e pela intensa busca de apoio aos projetos defendidos em épocas anteriores, ou como alternativas viáveis aos que estavam em voga. De fato, menos de dois meses após aquele pronunciamento, o mesmo Salles Torres Homem assinalaria o rompimento com Souza Franco. Ele alegava que depois de muito tempo juntos era penosa a separação, mas não podia mais acompanhá-lo no que dizia respeito a seus planos na área econômica. ${ }^{23}$ Curiosamente, 0 desentendimento ficou claramente inscrito nos anais da Câmara dos Deputados e marcará o começo da grande rivalidade desse período entre o Visconde de Inhomirim e o Visconde de Souza Franco, ambos convidados a assumir o cargo de ministro da Fazenda, ambos com projetos ambiciosos sobre a configuração do sistema bancário e monetário, ambos com apoio suficiente para insinuar grandes mudanças na economia.

Em linhas gerais, o projeto de Bernardo de Souza Franco objetivava a formação de uma grande malha de bancos que regularizassem o numerário de acordo com as necessidades dos mercados conferindo elasticidade ao meio circulante. Lidava, portanto, com a idéia da formação de um sistema bancário privado e autônomo que empregaria os capitais ociosos nas localidades para que eles fornecessem o combustivel da expansão econômica. Este seria o grande argumento dos que apoiavam a expansão do crédito, o crescimento da economia. Não foi à toa que, quando deputado, Souza Franco tendeu a atacar o projeto de melhoria do meio circulante defendido pelo Visconde de Itaboraí, alegando que este plano apresentava prejuízos à ampliação do crédito. ${ }^{24}$ 
25

Ministério da Fazenda. Proposta e relatório apresentados á Assembléia Geral Legislativa na Segunda Sessão da Décima Legislatura pelo Ministro e Secretário d'Estado dos Negócios da Fazenda Bernardo de Souza Franco. Rio de Janeiro: Typ. Nacional, 1858. p.6.

26

Ibidem, p.5.

27

Para estas posições de Bernardo de Souza Franco, CARVALHO, José Murilo de. 0 teatro das sombras..., Op. Cit., p.348.

28

NABUCO, Joaquim. Um estadista do império.... Op. Cit. Vol. 1. p. 190.

Anais da Câmara dos Deputados, sessão de 8 de agosto de 1857. p.223. A discussão se deu no dia 7. No entanto, a votação está marcada na folha do dia seguinte, dia 8.
Foi imbuído dessas crenças que ele respondeu ao problema de falta de metais e notas do tesouro enfrentado pela praça carioca e entendido, em 1858, como um flagelo de "sangria de moeda".25 À frente do Ministério da Fazenda, o Visconde de Souza Franco, autorizou a elevação da emissão do Banco do Brasil, bem como da instalação de 5 bancos privados: o Banco Comercial e Agrícola do Rio de Janeiro, um banco da província de São Pedro, um novo Banco de Pernambuco, o Banco do Maranhão e o Banco da Bahia. ${ }^{26}$ É preciso não perder de vista que o Ministro da Fazenda adotou as medidas que acreditava serem necessárias para combater problemas imediatos, entre elas, o da evasão de moeda do Sudeste. Não se tratava de mudar estruturalmente a política econômica simplesmente por possiveis colorações políticas em uma inversão automática e deslocada do contexto. Pelo contrário, mesmo com tendências liberais e ligado ao comércio urbano, ele respondeu à conjuntura da época e, se por um lado liberou a emissão bancária concernente com seu projeto, por outro não hesitou ao contrair empréstimos em Londres para salvar o Banco do Brasil e evitar uma "falência em massa".27

Os planos deste ministério destoavam do período anterior, especialmente por ser contra o que se dizia ser, o monopólio do crédito pelo Banco do Brasil. Segundo Joaquim Nabuco:

0 monopólio (de emissão) do Banco do Brasil, facultando-Ihe o governo, à medida que escoava o oiro (sic) de seus cofres, aumentar as suas emissões, não podia de certo regular de modo normal e eficiente a circulação fiduciária do país; comercialmente, financeiramente, o sistema era ruinoso, ainda assim deve-se ao gabinete Paraná ter impedido o incêndio de lavrar com a intensidade que a especulação desejava e que um momento sob o seguinte ministério ameaçava tudo conflagrar. ${ }^{28}$

A ascensão e o tempo de permanência de Souza Franco, frente ao ministério, podem indicar que o monopólio de emissão e do crédito pelo Banco do Brasil não gozavam mais de tanto apoio quanto entre 1854 e 1856.

No entanto, esta nova política econômica também sofreu resistência. Isso ficou claro na dificuldade que as medidas apoiadas por Bernardo de Souza Franco tiveram para ser aprovadas nos debates na Câmara dos Deputados. Um exemplo está no embate entre dois projetos para configurar o sistema bancário, um deles de autoria de Francisco de Sales Torres Homem e seu grupo, e outro apresentado pelo Barão de Mauá. 0 preferido pelo ministro da Fazenda era o plano do Barão de Mauá, uma vez que facilitava a instalação de bancos provinciais. Em diversos momentos, a impressão que se tem, ao acompanhar o desenrolar dos debates, é que o projeto apoiado pelo ministro sofreria uma derrota. Nesse momento ganhou toda sua dimensão a estratégia política para a aprovação das medidas. No último dia de discussão do projeto da reorganização do sistema bancário, 07 de agosto de 1857, o presidente do conselho de ministros, o Marquês de Olinda, tomou parte na sessão. Fez um discurso duro no qual criticava vários pontos do projeto de Francisco de Sales Torres Homem e reafirmava o apoio ao seu ministro da Fazenda. Terminado o discurso, ato contínuo, deu-se a votação e foi "aprovado o projeto substitutivo do Sr. Barão de Mauá". ${ }^{29}$

Em 1858 já era possível notar certo desgaste deste ministério. Parte de seu enfraquecimento se deu pelo aumento de aversão ao seu plano econômico. É claro que os reflexos da crise internacional são importantes para a compreensão do malogro nos resultados de seu projeto econômico. 
30

Anais da Câmara dos Deputados, sessão de 17 de maio de 1858. p. 31.

31

NABUCO, Joaquim. Um estadista do império... Op. Cit. Vol. 1. p.313.
No entanto, é preciso admitir que a política implementada parecia não ter sido suficiente para garantir a expansão econômica propalada pelo ministro. Não espanta que esse ano tenha sido marcado pelo aumento de críticas por parte dos descontentes com a política de pluralidade bancária e expansão do crédito. Jerônimo José Teixeira Júnior, o Visconde do Cruzeiro, deputado representante da província do Rio de Janeiro, mostrou-se um dos mais exaltados na cobrança da realização das promessas feitas por Bernardo de Souza Franco.

É evidente, Sr. Presidente, que entre as inúmeras questões que debalde reclamam uma decisão urgente do poder executivo sobressai como uma das mais importantes a questão bancária (...). À vista das idéias proclamadas pelo gabinete imperial, e das suas teorias sustentadas pelo intermédio do seu legítimo órgão, o Sr. Ministro da fazenda, sobre o desenvolvimento do crédito, parecia que não sofreriam o mínimo de embaraço em sua prática e realização (...). É portanto fora de dúvida que, depois da conduta e promessas feitas nesta casa pelo nobre ministro da fazenda por ocasião da discussão do projeto concernente às sociedades comanditárias, não era possível hesitar o governo imperial no cumprimento e execução dos compromissos que tomara para com o país. $^{30}$

Joaquim Nabuco apontou que o monarca também estava descontente com a nova política bancária, "0 Imperador era contrário às idéias financeiras de Souza Franco, e, se não inclinava para os Conservadores 'puritanos', preferia ver encerrada a fase das emissões discricionárias e continuado o ascendente do espírito moderado ou conciliador". ${ }^{31}$ De outra forma, indicava que havia sido a forte oposição do Senado que causara a queda do gabinete. Os indices, como visto anteriormente, também não favoreciam o ministério. Balança comercial deficitária, queda sensivel da taxa de câmbio - um importante indicador da época - e a manutenção do alto índice de custo de vida no Rio de Janeiro ajudam a entender o conjunto de motivos que fragilizaram o gabinete. Deste modo, à queda do gabinete Olinda-Souza Franco assumiu o novo gabinete, chefiado por Antônio Paulino Limpo de Abreu, o Visconde de Abaeté, e dele faziam parte dois dos maiores opositores do Visconde de Souza Franco, a saber, Francisco de Sales Torres Homem, na pasta da Fazenda, e Sérgio Teixeira de Macedo, na pasta do Império.

No Relatório do Ministério da Fazenda apresentado pelo futuro Visconde de Inhomirim, havia uma espécie de frustração generalizada pelo estado do sistema monetário e bancário. Os argumentos utilizados por ele foram que o meio circulante se encontrava em um estado calamitoso, e que havia excesso de notas em circulação e quase nenhum metal. A responsabilidade por essa situação recaía nos bancos de emissão, até mesmo do Banco do Brasil, que fora seduzido pela ilusão da "distribuição exagerada de crédito". Destacava que a instalação de bancos de emissão tinha solapado seu papel, uma espécie de regulador da economia. Assim, a situação apresentava um imenso obstáculo à ação do governo na melhoria do meio circulante. Mesmo que ele forçasse o pretenso regulador da economia a diminuir sua emissão, os demais bancos a aumentariam para captar os interessados. Os problemas cotidianos se agravaram quando a economia sofreu grandes oscilações em suas transações, afetando o comércio e a produção. Nesse momento, os agentes precisaram urgentemente de capital que, por sua vez, estava imobilizado em investimentos de retorno muito demorados. 
32

Ministério da Fazenda. Proposta e relatório apresentados á Assembléia Geral Legislativa na Terceira Sessão da Décima Legislatura pelo Ministro e Secretário d'Estado dos Negócios da Fazenda Francisco de Sales Torres Homem. Rio de Janeiro: Typ. Nacional, 1859.

33

Anais da Câmara dos Deputados, sessão de 22 de junho de 1859. p.200.

34

Idem, sessão de 1 de julho de 1859. p.9.

\footnotetext{
35

Idem, sessão de 8 de julho de 1859. p.57.

36

NABUCO, Joaquim. Um estadista do império..., Op. Cit. Vol. 1. p.328.
}

Em tom de desespero o ministro afirmava que a situação em que se encontravam era pior do que a de 1853. Todos os bancos tinham sérios problemas com relação à emissão-fundo de reserva, e muitos tinham seu fundo formado por títulos que, em um momento de pânico, não encontrariam compradores. A imagem que o ministro passa é desoladora. Como medida emergencial caçou a autorização dada ao Banco do Brasil para que emitisse o triplo de seu fundo disponivel, e apelava ao Legislativo por medidas que pudessem sanar a circulação. ${ }^{32}$ Foi com estas preocupações, fundamentalmente, a fragilidade do sistema bancário e o risco para a economia, que ele se empenhou ao máximo na aprovação de um projeto saneador para a economia. Basicamente, propunha que os bancos estariam obrigados a realizar suas emissões em ouro no prazo máximo de 3 anos e, enquanto isso, deveriam ater suas emissões ao montante lançado entre os meses de fevereiro a maio de $1859 .{ }^{33}$ Estas medidas representavam um enorme risco aos bancos mais modestos pois eles dificilmente conseguiriam atingir esse fim. As críticas ao projeto retomavam o problema da evasão de ouro da economia nacional, e colateralmente previam-se grandes problemas para a agricultura e indústria. 0 deputado João Lustosa da Cunha, representante do Piauí e futuro $2^{\circ}$ Marquês de Paranaguá, destacava:

$$
\begin{aligned}
& 0 \text { ouro assim exigido, estando a balança do comércio contra nós, há de vir-nos } \\
& \text { por empréstimo com os ônus que Ihe são inerentes; e como a exportação do país } \\
& \text { não é suficiente para fazer face à importação, a reserva metálica não permanecerá } \\
& \text { nos bancos, como nunca pôde permanecer no Banco do Brasil, tornará a sair, } \\
& \text { e esta operação terá de ser repetida incessantemente, ficando destarte aquele } \\
& \text { estabelecimento condenados ao suplício das Daneides (apoiados), e não haverá meio } \\
& \text { de encher o vácuo. }{ }^{34}
\end{aligned}
$$

Além da oposição dos grupos que tinham interesse direto em contrapor-se a este plano de reforma dos bancos como, por exemplo, os banqueiros, os tomadores de empréstimos e os que se lançavam a novas empresas, Francisco de Sales Torres Homem granjeou a oposição de políticos para os quais uma medida dessa gravidade só poderia ser adotada com farta documentação que comprovasse sua adoção. Isso porque o ministro, acreditando que esta estratégia garantiria uma aprovação mais rápida, optou em fazê-la passar como uma questão ministerial, vale dizer, criou uma disputa entre o ministério e a Câmara dos Deputados, ou passava a medida ou caía o ministério. José Antônio Saraiva foi um dos grandes críticos a esta situação e alertava o ministro que "essa questão é uma daquelas que precisam ser estudadas e resolvidas sem constrangimento algum".35 De fato, o desgaste do ministério antecedeu-se à aprovação do projeto. ${ }^{36}$

0 gabinete de 10 de Agosto foi recebido pelos que se opunham à restrição como uma vitória da expansão do crédito e das emissões. Em seu Relatório, Ângelo Moniz da Silva Ferraz fez uma análise detalhada da sociedade e dos problemas que ela enfrentava. Sua apreciação deixa às claras a necessidade de uma reorientação nos rumos da política econômica. Elaborou um ataque contumaz às Sociedades Anônimas que, segundo ele, muitas vezes funcionavam sem autorização, trazendo um prejuizo irreparável às que seguiam a lei. Retomava as determinações do Alvará de 30 de março de 1818, o Decreto de 12 de Agosto de 1825, bem como o Código de Comércio pelo artigo 295, para demonstrar que qualquer corporação ou sociedade, fosse ela com fins religiosos, científicos ou industriais, tinha por obrigação pedir autorização ao governo sobre seus estatutos. 
Afirmava ainda que muitas dessas sociedades emitiam notas, em um simulacro das atividades restritas aos bancos de emissão.

Tamanha preocupação estava relacionada com a quantidade de empreendimentos que funcionavam sem a aprovação dos seus estatutos e em atividades que colocavam em risco a ordem pública. Como não providenciaram nenhuma formalidade, campeava nestes negócios o completo despreparo, o que se refletia na direção dos seus negócios. Algumas companhias de seguro, por exemplo, aplicavam seu fundo de garantia em operações de empréstimo e descontos. 0 ministro chamava estes fatos à tona para demonstrar a necessidade de providências urgentes que assinalavam uma maior tutela e inspeção do governo sobre as atividades econômicas. Tomava como exemplo os Estados Unidos da América onde, segundo ele, o Poder Legislativo se reservava o direito de rever, emendar, suspender ou revogar a autorização de funcionamento concedida.

No Relatório, pairava um ar de incredulidade com relação aos ban$\cos$, daí o fato de ter formado e encarregado uma comissão para efetuar uma investigação e descobrir em que condições as instituições estavam. Fez, também, uma análise do Banco do Brasil, chegando à conclusão que, depois de operar algum tempo em desacordo com suas diretrizes de calma e moderação, aparentemente, retornara ao papel previsto em sua fundação.

Os demais bancos, no entanto, caracterizavam-se por um estado lastimável. Alguns emitiram papéis em excesso considerando que parte deles seria extraviada; outros, preocupados apenas com os lucros da emissão, concederam crédito além da capacidade de pagamento dos devedores. Muitas vezes, as emissões das caixas filiais que, por lei, deveriam ficar restritas às suas localidades, circulavam sem o menor impedimento na Corte. Havia casos impressionantes nos quais, para aumentar seus lucros, algumas instituições venderam o próprio fundo metálico aproveitando uma alta momentânea no preço do ouro. Alguns estabelecimentos, mantendo em seus fundos de reserva ações, chegavam a contabilizar a cotação futura dessas ações a seu favor, antecipando vultosos lucros que em nada correspondiam à realidade. Esta situação contrapunha-se àquilo que fora uma bandeira nas discussões da década anterior, ou seja, a garantia de que parte do fundo fosse metálico para gerar um mínimo de confiança na solidez dos sistemas bancário e monetário.

0 que mais alarmava era a imensa quantidade de bilhetes de banco em circulação, pois reafirmava a crença na expulsão à moeda metálica de circulação. Ao que parece, Ângelo Moniz da Silva Ferraz optou pela prudência nos primeiros momentos à frente da pasta da Fazenda. Tentava, desta forma, distanciar-se da acidez do debate travado pelo seu antecessor e chegou a declarar que não era continuador de política alguma. ${ }^{37}$ Não é preciso um esforço muito grande para notar que as principais preocupações do seu Relatório deram origem à reforma de 1860, conhecida posteriormente como a Lei dos Entraves. Ela previa que:

Art. $1^{\circ}$. Nenhum dos Bancos criados por decretos do Poder Executivo poderá emitir, sob a forma de notas ou bilhetes ao portador, quantia superior ao termo médio de sua emissão operada no decurso do primeiro semestre do corrente ano, enquanto não estiver habilitado para realizar em ouro o pagamento de suas notas; exceto se, além do fundo disponivel ou de garantia e das outras condições estabelecidas nos respectivos estatutos, tiver em caixa parte de seu capital equivalente ao excesso do dito termo médio de emissão e for esta parte representada por moeda de ouro ou barras do mesmo metal do toque de vinte dois quilates, ou por barra de prata de 
38

Coleção das Leis do Império do Brasil. 1860. Tomo XXI. Parte I. p.28-36. Versão eletrônica disponivel no site: http://www.camara.gov.br/ Internet/InfDoc/conteudo/colecoes/Legislacao/ leis1860/leis1860-1.pdf

39

NABUCO, Joaquim. Um estadista do império..., Op. Cit. Vol. 1. p.336.

40

Anais da Câmara dos Deputados, sessão de 6 de agosto de 1860. p.70. onze dinheiros na relação fixada pelo art. $3^{\circ}$ do Decreto $n^{\circ} 1.721$ de 54 de fevereiro de 1856, com tanto que o valor destas não exceda à quarta parte do da moeda e barra de ouro.

\section{(..)}

§3. Se no fim do prazo de um ano, contado da publicação desta lei, os Bancos não se acharem ainda habilitados para trocar suas notas por moeda de ouro, o Governo fará restringir anualmente, enquanto não conseguirem este resultado, a soma das notas ou bilhetes em circulação, na proporção que marcará o acordo com os mesmos bancos:

(...)

§5. Será considerado falido o banco de circulação que não satisfizer à vista e em moeda corrente, ou, verificadas as hipóteses do pagamento previstas pelo parágrafo antecedente, em moeda de ouro, à vontade do portador, a importância de seu bilhete ou nota apresentada a troco; e pelo tempo da mora o portador terá direito ao juro corrente. Nas mesmas penas incorrerão os bancos que violarem as disposições dos $\S \S 1^{\circ}, 2^{\circ}, 3^{\circ}$ e $4^{\circ}$ deste artigo (...). ${ }^{38}$

É importante notar que, se de um lado a questão da solidez bancária e da credibilidade do meio circulante estavam encaminhadas rumo ao que parecia ser uma solução definitiva, por outro, a falta de meio circulante ainda era um fantasma que assombrava a economia e, frequentemente, forçava os limites impostos pelo governo ao sistema monetário. Ironicamente, a ascensão daquele que daria continuidade à conciliação, como desejava o Imperador, marcou o revés decisivo na política de Souza Franco. Segundo Joaquim Nabuco, Francisco de Sales Torres Homem, com certa amargura, declarou "Ao ministério de 10 de Agosto competirá a glória merecida de haver realizado este importante melhoramento, que nós, os ministros de 12 de Dezembro, não fomos bastante felizes para realizar apesar de nossos esforços e dedicação". 39

0 discurso de Joaquim Gomes de Souza, representante da província do Maranhão na Câmara dos Deputados, ilustrava bem a grande transformação da questão e indicava o motivo para essa mudança. 0 deputado demonstrava certo estranhamento em como se podia discutir "com tanta calma" uma questão que ha poucos meses havia fracionado tão profundamente a casa ${ }^{40}$ Segundo ele, a menor resistência ao projeto - que de outra forma era o mesmo apresentado no ano anterior - ocorreu pela estratégia adotada por Ângelo Moniz da Silva Ferraz, o futuro Barão de Uruguaiana. Ao invés de apresentá-lo como uma questão ministerial, o ministro apresentou-o para que sofresse todas as alterações que o Senado e a Câmara dos Deputados julgassem necessários. Assim, muitos políticos parecem ter abandonado a oposição ao projeto e passaram a discuti-lo levando em conta seus argumentos econômicos e obtendo sua aprovação. Desta feita, a década seguinte, 1860, foi o cenário no qual dialogaram as restrições à emissão e as necessidades da economia real em uma conversa nem sempre amistosa.

\section{Conclusão}

0 ano de 1850 apresentou-se como um grande momento de reorganização na história do Brasil. Nesse ano aprovaram-se medidas que repercutiram nas áreas mais vitais da sociedade. É deste momento a aprovação da Lei 
que previa o fim do tráfico intercontinental de escravos africanos, base da mão-de-obra utilizada no Brasil. Isso impunha à sociedade a tarefa de vislumbrar uma fonte substitutiva para o fornecimento de trabalhadores, sob o risco de inviabilizar sua produção.

Com a área financeira não foi diferente. Não se deve esquecer medidas menos conhecidas, mas não menos importantes, como a provincialização do meio circulante e a posterior aprovação do banco nacional. Mais do que a simples coincidência de datas, essa legislação foi resultado de longos debates, sucessivas reelaborações nas estratégias e adaptações na redação das leis. Para apreender melhor o impacto que esse momento teve tratei de manter sempre em mente as expectativas depositadas nos projetos, 0 esforço de alguns articuladores na aprovação de tais medidas e, especialmente, do que essas medidas representavam para eles. Significava a transformação da sociedade rumo ao ideal de civilidade e crescimento. Longe da aprovação dessa ampla legislação significar o fim dos debates sobre os temas que as fomentaram, elas representavam um instante especifico de vitórias de alguns grupos envolvidos na defesa dos projetos. Os problemas surgidos a partir da execução das medidas, as resistências e a frustração pelos resultados motivaram novos debates e projetos, estes novamente repletos de expectativas e anseios na busca pela dinamização da economia e da sociedade brasileira.

Como este artigo está inserido em um esforço maior, que busca integrar as discussões realizadas nas principais instâncias decisórias do governo apresento, a seguir, algumas conclusões preliminares. A saída de moeda metálica da praça carioca mostrou-se persistente por quase todo o período estudado. Na realidade o padrão ouro parece ter operado a favor da economia brasileira em pouquíssimos momentos, segundo os discursos, um deles em 1851. A impressão de que as demais provincias atuariam como sorvedouros de moeda foi uma realidade e estava ligada à maneira como as políticas econômicas eram pensadas nessa época. É preciso levar em consideração que não se tratava de uma economia completamente integrada, mas sim de várias economias regionais com dinâmicas diferentes. Algumas estavam em crescimento e apresentavam fortes flutuações em suas transações comerciais; outras poderiam apresentar crises por conta de fenômenos locais, como era o caso das grandes secas que afligiam algumas províncias do Nordeste. Era sobre esta base multifacetada que se desenvolveu a questão da moeda.

A abertura de novas áreas produtivas também demandava moeda e acabava por forçar as regras instituídas pelo governo em atividades consideradas, em muitos momentos, ilegais, como foi o caso da emissão de vales ao portador. Desta forma, a economia real apresentava-se em toda sua rebeldia, especialmente, nos momentos de crise. Por outro lado, não se pode perder de vista a esperança que os arquitetos dos projetos depositaram neles, no começo da década de 1850 . 0 conjunto de transformações institucionais que tanto espanto causa nos dias atuais representava para eles a mudança. Era o começo de um novo tempo, se assim se quiser categorizar aquele momento histórico, um momento repleto de idéias e realizações, vinculadas a uma lenta dissolução de heranças herdadas ainda do período colonial. E este tempo, como de fato todos os outros, se desfez na dinâmica econômico-social. Desfez-se no lento e gradual choque dos anseios com resultados inesperados, de uma economia que insistia em não se adequar plenamente aos planos tão 
cuidadosamente elaborados. 0 tempo impôs reformulações que eram, amiúde, testados pelas conjunturas econômicas.

A legislação de 1860, que pressupunha uma reserva metálica suficiente para realizar o troco das notas dos bancos, não pode ser plenamente compreendida se tomada de forma isolada. Este desfecho provisório continha certo rancor com a gestão de Bernardo de Souza Franco, responsável pela mudança na política econômica implantando a pluralidade bancária, mas provinha também da percepção de que o projeto de melhoria da moeda não dera os resultados esperados. A opção pela adoção do padrão-ouro baseada na crença da entrada de metais na economia brasileira, por outro lado, impunha o problema da falta dessa mesma moeda para a economia. Paralelamente a isto, o ritmo de crescimento das economias provinciais, muitas vezes, pressionou a economia carioca com tamanha força que ela não conseguia suprir de maneira satisfatória as outras regiões com moeda.

Talvez esteja aí parte da explicação da adoção de medidas concernentes ao aumento de emissão, especialmente em momentos críticos, como o de 1857. Destarte, a década de 1860 deve ser encarada como um novo período na busca de melhoria do meio circulante. Os efeitos da adoção da Lei dos Entraves devem ter iniciado novas discussões marcadas, ao que tudo indica, mais pela experiência do caso brasileiro do que pelas doutrinas teóricas. De antemão, pode-se vislumbrar que a pressão por crédito deve ter crescido, especialmente, nas províncias mais afastadas de grandes centros uma vez que a restrição às emissões também aumentaram. 